\title{
Survey Results Document Exploitative Labour Conditions in China"s Construction Sector
}

\author{
The ESRC-DFID Research Project \\ "Labour Conditions and the Working Poor in China and India"
}

This Development Viewpoint represents Part II of a report on labour conditions in China's construction sector. Its findings derive from the ESRC-DFID Research Project on Labour Conditions and the Working Poor in China and India.

Between late 2011 and early 2013, this project carried out a direct survey of construction workers and in-depth interviews and focusgroup discussions with key informants in the construction sector in the general Shanghai area.

The results of this survey document, in more detail, the deterioration in labour conditions that Part I, Development Viewpoint \#77, discussed in general terms. Part I highlighted how the large number of migrant construction workers from rural areas have borne the brunt of exploitative conditions in the sector.

\section{Demographic Characteristics}

The survey shows, not unexpectedly, that about $97 \%$ of the workers in this sector are men. More noteworthy is that the average age of all workers is relatively old, namely, 41 years, with the majority of them being between 30 and 50 years of age.

These workers face limited opportunities to move into better urban jobs. Meanwhile, younger workers from rural areas prefer to secure jobs in better-paid sectors such as manufacturing. Correspondingly, the average years of job experience in the sector are relatively high, namely, 13 years. In fact, over one fifth of workers have laboured in the sector for more than 20 years.

About $62 \%$ of all construction workers have families with 4-5 members and another $20 \%$ have 6 members or more. Critically, $37 \%$ of all workers are not earning enough money to support their parents. Usually, workers support not only their spouse but also at least one parent and one child.

About one-third of workers are either illiterate or have received only a primary-level education. Another $47 \%$ have received only a junior secondary level of education. This generally low level of education is consistent with the low level of qualifications needed for construction work.

\section{Working Hours and Overtime}

The working hours of construction workers tend to be long, ranging between 8 and 12 hours, with the average being 9.5 hours. About $45 \%$ of workers have replied that they work 10 hours a day and another $7 \%$ have stated that they work more.

There are also notable differences in the number of days worked per month. For example, about $30 \%$ of respondents have indicated that during some periods they have worked continuously for 30 days without any break.

Construction workers rarely have days off during Sundays or statu- tory holidays. In fact, $85 \%$ of them receive no special compensation for working on weekends and another $82 \%$ receive no extra pay for working on holidays (see Table 1). In addition, $42 \%$ of workers receive no special pay for working overtime during the regular work week. Such lack of compensation for overtime is the source of a great deal of worker discontent.

Table 1. Percentages of Workers Not Receiving Overtime Pay

\begin{tabular}{|l|c|c|c|}
\hline & Received & Did Not Receive & Did Not Know \\
\hline $\begin{array}{l}\text { Weekday } \\
\text { Overtime }\end{array}$ & $51 \%$ & $42 \%$ & $7 \%$ \\
\hline $\begin{array}{l}\text { Weekend } \\
\text { Overtime }\end{array}$ & $10 \%$ & $85 \%$ & $5 \%$ \\
\hline $\begin{array}{l}\text { Holiday } \\
\text { Overtime }\end{array}$ & $11 \%$ & $82 \%$ & $7 \%$ \\
\hline
\end{tabular}

Source: Survey Data

\section{Wages and Wage Arrears}

The great majority of workers receive daily wages that range between 100 and 200 Yuan (or about US\$16 to US\$32). However, the period over which workers receive their wages differs widely.

Over half, $53 \%$, receive their wages only on a yearly basis. Another $25 \%$ receive their wages at the end of the construction project. And a mere $9 \%$ of workers receive their wages on a monthly basis.

Wage arrears have been a significant problem for construction workers. About $36 \%$ of them have experienced this problem at one point or another during their employment.

Is low pay a major concern for Chinese construction workers? This does not appear to be their primary grievance. One reason is that the wage payments of many workers tend to exceed the returns from their previous occupations as farmers on small agricultural plots.

Moreover, most of the families that they have left behind can still eke out at least subsistence incomes from these plots. On average, incomes from such plots have accounted for about one-third of the total income of the families of construction workers.

But even taking all family income sources into account, about onetenth of construction workers still belong to families with total yearly household income less than 20,000 Yuan (or less than about US\$3,200).
The contents of this Development Viewpoint reflect the views of the author(s) and not necessarily those of CDPR or SOAS. 
The worker survey also provides interesting findings on who pays workers their wages and whom they regard as their boss. About three-quarters of construction workers are paid directly by a labour subcontractor. It is not surprising then that about two-thirds of workers mistakenly regard these subcontractors as their employers.

\section{Filing Grievances}

One of the most striking findings of the survey is that $78 \%$ of all workers have not signed labour contracts with their employers. In addition, among the $22 \%$ of workers who have signed contracts, a third of them do not even have a copy.

Thus, the great majority of construction workers are unable to lodge formal grievances on their pay, working conditions or social protection.

The survey found that if construction workers experienced problems such as wage arrears or poor working conditions, $81 \%$ of them would seek help from government Labour Bureaux. However, these bureaux tend to be woefully understaffed.

Strikingly, less than $6 \%$ of workers would seek help from a trade union. In fact, about $70 \%$ of all construction workers have had no contact with a union.

\section{Workers' Main Problems}

The survey has also explicitly asked construction workers about what they regard as their main problems (See Table 2). In response, $41 \%$ point to the lack of a labour contract.

Another $41 \%$ of workers identify deficiencies in social insurance. Insurance related to occupational safety and health is a particular concern. For example, about $60 \%$ of workers have had to buy their own safety equipment. And over $18 \%$ of workers have experienced work-related injuries or occupational diseases.

Table 2. Major Perceived Labour Problems (\% of Workers Identifying a Problem)

\begin{tabular}{|l|c|}
\hline \multicolumn{1}{|c|}{ Labour Problem } & Percentage of Workers \\
\hline No Labour Contract & $41 \%$ \\
\hline Lack of Social Insurance & $41 \%$ \\
\hline No Extra Pay for Hot Summer Work & $38 \%$ \\
\hline Late Wage Payments & $31 \%$ \\
\hline No Union Representation & $30 \%$ \\
\hline
\end{tabular}

Source: Survey Data

Another $38 \%$ of workers complain about the lack of extra compensation for working under hot summer conditions. Lastly, $31 \%$ of workers identify the problem of late payment of wages and $30 \%$ the lack of union representation.
The late and/or irregular payment of wages is perceived to be a greater problem than wage levels by construction workers. For example, less than $10 \%$ of workers call for increases in daily wages. This response suggests, again, that low pay itself is not the dominant concern among these workers.

The lack of effective provisions for social insurance, such as compensation for work-related injuries or medical insurance, appears to be a greater priority than higher wages for many of the workers. In addition, long hours and the intense pace of work are also regarded as more severe problems.

\section{Concluding Remarks}

The results from the survey of construction workers and key informants in Shanghai highlight the need for major reforms in the structure and functioning of this sector and significant improvements in labour conditions and worker representation.

The increasing emphasis on profit maximisation of the construction industry has led to the widespread prevalence of exploitative labour conditions for the majority of its workers.

Development Viewpoint \#77 explained how the most damaging effects of runaway profit maximisation have fallen on the large number of migrant workers from rural areas who constitute the great majority of construction workers in the Shanghai area.

These migrant workers have either no formal right to reside in urban areas or only a temporary right based on their work status. As a consequence, for many of these workers, their job in construction represents a virtual dead-end. Even though working conditions are generally harsh, most workers have to remain in the sector for many years.

And in doing so, they face daunting challenges: there is high work intensity, no formal limitation on the number of hours of work per day or per month, no standard rates for overtime pay, and virtually no regularised payment of wages nor provision of social protection.

Lastly, the great majority of construction workers (especially migrant workers) have little recourse in trying to redress their grievances, either through government channels, such as Labour Bureaux, or through their own organisations, such as trade unions.

This Development Viewpoint draws exclusively on results from the survey efforts in the greater Shanghai area led by Chinese researchers at Hong Kong Polytechnic University (Professor PUN Ngai) and Peking University (Professor LIU Aiyi and Dr. LU Huilin). They were assisted by NG Tsz Fung Kenneth of the Chinese University of Hong Kong, CHEN Wei of the Hong Kong Baptist University and TANG Weifeng of Peking University.
The contents of this Development Viewpoint reflect the views of the author(s) and not necessarily those of CDPR or SOAS. 